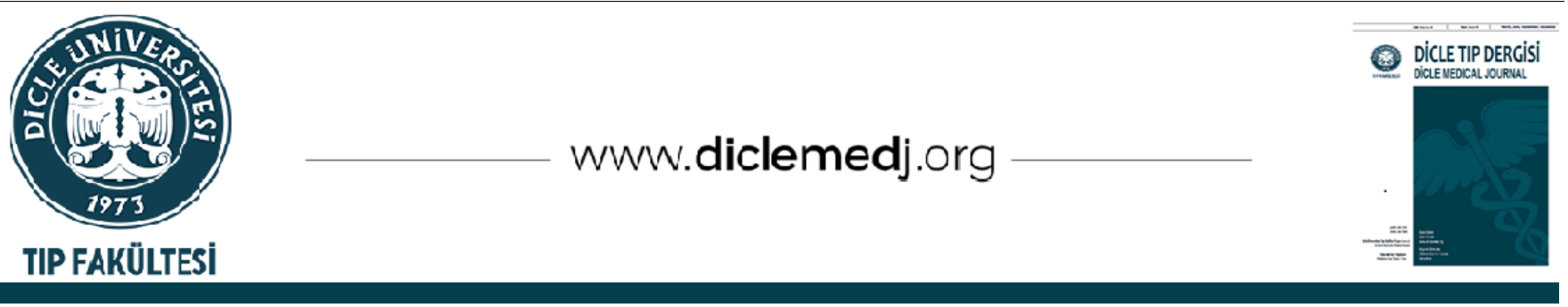

Original Article / Özgün Araştırma

\title{
Neonatal Supraventricular Tachycardia: Outcomes Over a 10-Year Period at a Single Institution
}

\author{
Hasan Akduman ${ }^{1}$, Dilek Dilli ${ }^{i}{ }_{1}$, Senem Özgür ${ }^{D_{2}}$, Başak Kaya Gürsoy ${ }_{1}$, Utku Arman Örün ${ }^{2}$, \\ Seda Aydoğan ${ }^{1}$, Rumeysa Çitli ${ }^{D}{ }_{1}$, Nurdan Dinlen Fettah ${ }_{1}$, Serpil Kaya Çelebi ${ }^{D_{2}}$, \\ Ayşegül Zenciroğlu iD 1 \\ 1 Department of Neonatology, Dr Sami Ulus Maternity and Children Research and Training Hospital, University of Health Sciences of Turkey, Ankara, Turkey \\ 2 Department of Pediatric Cardiology, Dr Sami Ulus Maternity and Children Research and Training Hospital, University of Health Sciences of Turkey, Ankara, \\ Turkey
}

Received: 14.07.2021; Revised: 16.09.2021; Accepted: 16.09.2021

\begin{abstract}
Objective: Supraventricular tachycardia, one of the most common conditions requiring emergency cardiac intervention in newborns, is also the most common symptomatic tachyarrhythmia in newborns. Therefore, early diagnosis and treatment approach is important.
\end{abstract}

Method: Demographic findings, clinical findings, and treatment approaches of newborns hospitalized with the diagnosis of supraventricular tachycardia between January 2011 and November 2020 in the Neonatal Intensive Care Unit of our hospital were evaluated retrospectively.

Results: Thirty-eight patients without congenital heart disease (except secundum-type atrial septal defect) and diagnosed with supraventricular tachycardia were evaluated retrospectively. The mean week of gestation was $38.2 \pm 1.8$, the mean age at diagnosis was $10.7 \pm 10.1$ days, the number of patients with heart failure was $8(21 \%)$, the number of patients with WolffParkinson White syndrome was 8 (21\%), the number of patients with fetal arrhythmia was $6(15.7 \%)$ and the mean number of hospitalization days was $15.7 \pm 13.5$. The patients were given adenosine in the first stage and propranolol, amiodarone, propafenone and flecainide in the second stage as medical treatment. Cardioversion was performed in 5 (13\%) patients due to resistant supraventricular tachycardia.

Conclusion: Early diagnosis and treatment of supraventricular tachycardia are very important in terms of reducing morbidity and mortality. Therefore, we think that increasing awareness of supraventricular tachycardia among clinicians following newborn babies will enable newborns with supraventricular tachycardia to receive early diagnosis and treatment.

Keywords: Supraventricular tachycardia; newborn; arrhythmia; antiarrhythmic drug

DOI: 10.5798/dicletip.1001875

Correspondence / Yazışma Adresi: Hasan Akduman, University of Health Sciences of Turkey, Dr Sami Ulus Maternity and Children Research and Training Hospital, Department of Neonatology 06590 Yenimahalle, Ankara, Turkey e-mail: akduman2004@yahoo.com.tr 


\section{Neonatal Supraventriküler Taşikardi: Tek merkez Deneyiminin 10 Yıllık sonuçları}

Öz

Amaç: Yenidoğanlarda en sık acil kardiyak müdahale gerektiren durumlardan biri olan supraventriküler taşikardi (SVT), aynı zamanda yenidoğanlarda en yaygın görülen semptomatik taşiaritmidir. Bu nedenle erken tanı ve tedavi yaklaşımı önemlidir.

Yöntemler: Hastanemiz Yenidoğan Yoğun Bakım Ünitesinde Ocak 2011-Kasım 2020 tarihleri arasında SVT tanısı ile yatırılan yenidoğanların demografik ve klinik bulguları ile tedavi yaklaşımları retrospektif olarak değerlendirildi.

Bulgular: Konjenital kalp hastalığı olmayan (sekundum tip atriyal septal defekt dışında) ve SVT tanısı alan 38 hasta retrospektif olarak değerlendirildi. Ortalama gebelik haftası $38.2 \pm 1.8$, ortalama tanı yaşı $10.7 \pm 10.1$ gün, kalp yetmezliği olan hasta sayısı 8 (\%21), Wolff-Parkinson White sendromlu hasta sayısı 8 (\%21), fetal aritmili hasta sayısı 6 (\%15.7) ve ortalama yatış gün sayısı 15.7 \pm 13.5 idi. Hastalara medikal tedavi olarak birinci aşamada adenozin, ikinci aşamada propranolol, amiodaron, propafenon ve flekainid verildi. Dirençli SVT nedeniyle 5 (\%13) hastaya kardiyoversiyon uygulandı.

Sonuç: Supraventriküler taşikardinin erken tanı ve tedavisi, morbidite ve mortaliteyi azaltması açısından oldukça önemlidir. Bu nedenle yeni doğan bebekleri takip eden klinisyenler arasında SVT farkındalığının artmasının bu yenidoğanların erken tanı ve tedavi almalarını sağlayacağını düşünüyoruz.

Anahtar kelimeler: Supraventriküler taşikardi; yenidoğan; aritmi; antiaritmik ilaç.

\section{INTRODUCTION}

Supraventricular tachycardia (SVT) is a heterogeneous array of arrhythmias and is traditionally characterized as a narrow complex tachycardia1,2. SVT is common in newborn infants and is the most common symptomatic tachyarrhythmia ${ }^{2,3}$. A general term for a nonsinus rhythm accelerated, resulting from an atrioventricular (AV) junction level between 200 and $300 \mathrm{bpm}^{1}$. SVT is a rare disease limited to only a few cases per year in each perinatal center ${ }^{3}$ and one of the most common conditions requiring emergency cardiac intervention in neonates ${ }^{1,4}$. Generally, its presence in the first days of life is more dramatic than SVT in later infancy and childhood. Although the prognosis is good in cases without cardiac anomalies, heart failure symptoms may be seen when cardiac anomalies are accompanied and they may even be born with hydrops. Therefore, it is extremely important to determine the prognosis ${ }^{3}$. Generally, patients with SVT do not have concomitant congenital heart disease ${ }^{5}$. Although many studies have been conducted on SVT in infancy and childhood, these studies have been relatively limited in newborns without structural heart disease. And they are usually included in the literature in the form of case reports. For this reason, we thought that it would be more appropriate to evaluate the cases with SVT seen in newborns without structural cardiac anomalies. Thus, we evaluated the outcomes of all neonatal SVT patients admitted to the neonatal intensive care unit (NICU) over a 10-year period. In this study, we aim that our experiences may be useful to NICU teams following-up neonatal arrhythmias.

\section{METHOD}

In this study, the newborns born between January 2011 and November 2020, admitted to the NICU of our hospital for the first 28 days of life, and diagnosed with SVT were evaluated retrospectively. Infants with congenital heart disease (CHD) (except patent foramen ovale; PFO, atrial septal defect; ASD), sepsis, metabolic disease, and central nervous system anomaly were excluded from the study. The 5 ASD cases in our study were secundum-type ASD and the diameter of the ASDs were $<3 \mathrm{~mm}$. Since ASDs were not hemodynamically significant, it was thought not to be the cause of SVT and was included in the study. This information is stated in the article. Ethics committee approval was obtained from the ethics committee of Dr. Sami 
Ulus Maternity and Children Research and Training Hospital, University of Health Sciences of Turkey (Ethics committee number: E-20/1236). The files of the patients and the hospital automation system records were examined. Demographic data, clinical findings, electrocardiography (ECG) and echocardiography (ECHO) findings, Holter monitor ECG evaluations, treatments, response to treatments, follow-up periods, and early prognosis of the patients were determined. Evaluation of the patients with echocardiography was done in the absence of SVT attack. SVT attack was diagnosed if the patient has tachycardia ( $\geq 180 / \mathrm{min})$ accompanied by the absence of $\mathrm{p}$ waves and a narrow or normal QRS duration in $\mathrm{ECG}^{2}$.

Data were recorded using SPSS 21.0 (SPSS Inc; Chicago, IL, USA). Descriptive statistics were used in the analysis of results were expressed. Mean (SD) for parametric variables or percent values for categorical variables were given. Results are expressed as mean with standard deviation or median with a range of data where appropriate. Frequency distribution was analyzed using chi-square or Fisher's exact test. The level of significance was determined as 0.05 in all comparisons.

\section{RESULTS}

In our study, a total of 24580 newborns were followed up in the NICU over a 10-year period and 38 newborns (without CHD) were diagnosed with SVT. The incidence of SVT for our unit was found to be $1.5 / 1000$. Hydrops fetalis and electrolyte imbalance was not observed in any of the patients. The demographic characteristics of the patients and their clinical features at presentation are given in Table1. One mother had Behçet's disease and two mothers had Hashimoto's thyroiditis. Other mothers had no known chronic disease. Fetal arrhythmia (SVT) was present in six (15.7\%) cases. Intermittent SVT was observed in all fetuses. It was observed that one of the cases received sotalol and flecainide in their antenatal follow-up, and the other case refused the treatment. It was observed that four cases did not take any medication (2 pregnant did not come to their follow-up, two pregnant did not need treatment). Eight patients (21\%) (6 of them were hospitalized 2 times, 2 of them were hospitalized 3 times) had a history of rehospitalization. None of the followed patients died. ECHO, ECG, and Holter monitor evaluations were performed in all of the patients (Table 2). To terminate SVT attacks, patients were administered 50-100 microgram $/ \mathrm{kg} /$ dose adenosine as an acute medical agent. In the patient who did not respond, the dose was gradually increased up to 300 micrograms $/ \mathrm{kg} /$ dose. Amiodarone was added to acute treatment in resistant cases. When the SVT attacks of the patients were brought under control, amiodarone treatment was discontinued by reducing it. And concurrently propranolol (most), propafenone, flecainide were used as second-line therapy (chronic therapy) (Figure 1). Since four patients had a very short $(<10 \mathrm{sec})$ SVT attack and this was confirmed with Holter monitor, the attacks were controlled with propranolol treatment alone, without the need for adenosine administration. The number of the patients receiving the highest number of treatments and/or their combinations is shown in figure 2 . Seven patients in the unclassified group (all received adenosine) received combinations of digoxin, sotalol, ivabradine, propafenone, propranolol, amiodarone, and flecainide. No side effects (hepatotoxicity, liver enzyme elevation, ventricular tachycardia, etc.) were observed due to the drugs used. Except for one patient, no complications related to SVT and cardioversion were observed. In this patient, cardioversion was performed when the SVT attack could not be controlled with adenosine. Necrotizing enterocolitis (NEC) developed 14 hours after cardioversion. And Pan-NEC picture developed in our patient who got worse and 
worse. Therefore, we applied intravenous mesenchymal stem cells to our patient. NEC recovered and the patient was discharged home in good health. However, the mesenchymal stem cell we gave caused hyperechogenicity (seen in ECHO) with a diameter of $5 \times 7 \mathrm{~mm}$ on the left ventricular papillary muscle. We think that this situation develops due to the mesenchymal stem cells we give after the heart damage caused by cardioversion. Because although our patient is now 3.5 years old, no change in the diameter of the hyperechoic image was observed.

Table I: Demographic and clinical presentation characteristics of the patients.

\begin{tabular}{|c|c|}
\hline Maternal age $(y)^{*}$ & $28.4 \pm 5.5$ \\
\hline Gestation week* & $38.2 \pm 1.8$ \\
\hline Preterm & $5(\% 13)$ \\
\hline Birth weight* & $3291 \pm 486$ \\
\hline Female gender, n (\%) & $17(44.7)$ \\
\hline Cesarean rate, $\mathrm{n}(\%)$ & $25(65.8)$ \\
\hline Age at diagnosis*, day & $10,7 \pm 10.1$ \\
\hline Parental consanguinity, n (\%) & $5(11.6)$ \\
\hline Cardiac pulse*, beats/min & $243 \pm 33$ \\
\hline Ejection fraction & $65.7 \pm 4.1$ \\
\hline Heart failure, n (\%) & $10(26.3)$ \\
\hline Fetal arrhythmia, n (\%) & $6(15.7)$ \\
\hline Length of hospital stay*, day & $15.7 \pm 13.5$ \\
\hline Rehospitalization ( $\geq 2$ times), n (\%) & $8(21)$ \\
\hline
\end{tabular}

*: mean \pm standart deviation
Table II: Echocardiography (ECHO), electrocardiography (ECG) and Holter monitor parameters of the patients.

\begin{tabular}{|l|c|}
\hline \multicolumn{2}{|c|}{$n(\%)$} \\
\hline ECHO & $17(44.7)$ \\
\hline PFO & $11(28.9)$ \\
\hline ASD & $5(13.2)$ \\
\hline MI + PFO & $1(2.6)$ \\
\hline MI & $4(10.5)$ \\
\hline Normal & $8(21.1)$ \\
\hline ECG & $19(49)$ \\
\hline Delta waves (WPW) & $8(21.1)$ \\
\hline HOLTER & $7(18.4)$ \\
\hline SVT & $3(7.9)$ \\
\hline SVT+WPW & $1(2.6)$ \\
\hline SVT +SVES & \\
\hline SVT+VES & \\
\hline SVT+VES+SVES & \\
\hline
\end{tabular}

PFO: Patent foramen ovale, ASD: Atrial septal defect, VSD: Ventricular septal defect, MI: Mitral insufficiency, WPW: Wolff-Parkinson-White, VES: Ventricular extrasystoles, SVES: supraventricular extrasystoles

Propranolol

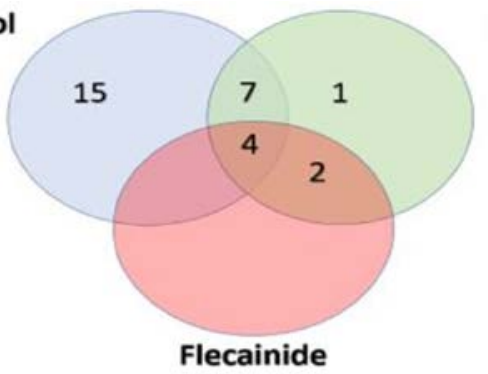

Propafenone

Figure 1: The most preferred second-line medical agents in patients with recurrent SVT attacks and the number of patients.

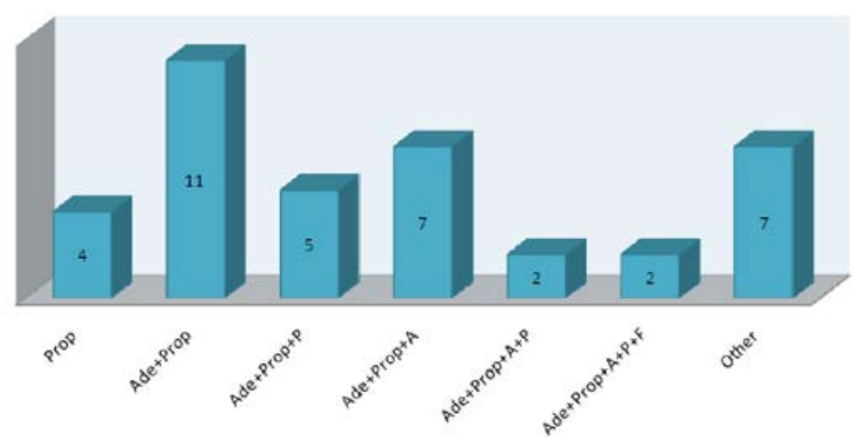

Figure 2: Number of the patients using antiarrhythmics and the distribution of drugs given.

Prop: Propranolol, Ade: Adenozin, P: Propafenon, A: Amiodaron, F: Flekainid, Other: Drug combinations with Sotalol, Digoxin, Ivabradin, Prop, Ade, $P, A$, and $F$ 


\section{DISCUSSION}

Although the frequency of arrhythmia is not high in the neonatal period, SVT is the most common symptomatic tachyarrhythmia in this period ${ }^{6-8}$. SVT is characterized as a narrow complex tachycardia ${ }^{1}$. In the majority of studies, the frequency of SVT was evaluated by including infants with cardiac anomalies in SVT cases and the incidence was found to be $1-4 / 1000^{9}$. A population-based study from the national birth cohort database in Taiwan found an incidence of $0.06 / 1000$ in newborn infants without cardiac anomalies in the neonatal period ${ }^{10}$. We found the frequency of SVT to be 1.5/1000 among patients hospitalized in the NICU of our hospital. As far as we know, there was limited information about the relationship between mode of delivery and SVT in studies in the literature. In our study, the frequency of SVT was approximately two times higher in babies born by cesarean section compared to babies born by normal vaginal route. Since we could not find any information about these results in the literature, we thought that this result might be a coincidence in order not to speculate about this situation. Most of the studies on SVT were retrospective and consisted of patient groups that included cardiac anomalies. We excluded cases with cardiac anomalies in our study. However, PFO and ASD were included in the study group because they usually did not cause problems such as surgery and heart failure in the early period of life. Similar to our study, Malekian et al. also included only ASD in a metaanalysis on 22 case series of neonatal SVT' ${ }^{8}$. Our findings were comparable to this study in terms of gender, prematurity rate, birth weight, gestational age, and age at diagnosis. In this study, the rate of ASD was lower than in our study. In Bjeloševič et al.'s study of 116 cases of newborns with SVT, the rate of admission to the hospital on the first day was $28 \% 11$. In our study, $52 \%$ of the patients were admitted to the hospital on the first day of life. We think that this early admission in our study may be related to close neonatal follow-up. In the SVT study of Gilljam et al., in which 109 newborn cases were followed, it was observed that the mean cardiac beat rate was $270 \pm 27 / \mathrm{min}$, and $48 \%$ of the patients had heart failure at the time of the first admission to the hospital ${ }^{3}$. In our study, the mean cardiac beat rate was found to be $243 \pm 33$, and the rate of heart failure was found to be $26 \%$. We think that the reason for our low rate of heart failure is that patients with major cardiac anomalies were excluded from the study.

Wolff-Parkinson White (WPW) syn drome is a type of atrioventricular re 7 entrant tachycardia. WPW is diag $\urcorner$ nosed in patients with a history of SVT and a baseline ECG that demonstrates sinus rhythm, shortened PR interval, and widened QRS complex with a characteristic delta wave ${ }^{1}$. $10-20 \%$ of the cases presenting with SVT in the neonatal period have a WPW pattern on the ECG $^{12}$. While the incidence of WPW syndrome was $9 \%$ in the study of Malekian et al., 8 it was found to be $30 \%$ in the study of Etheridge et al. ${ }^{13}$. In our study, this rate was found to be $21 \%$.

The frequency of fetal tachyarrhythmia in pregnant women is $0.4-0.6 \%$, and $70-80 \%$ of this is due to SVT14,15. Fetal SVT can be intermittent or continuous. Fetal SVT, especially longer than 12 hours and continuous; can cause heart failure, hydrops fetalis, and fetal loss and requires treatment with antiarrhythmic drugs that can cross the placenta. On the other hand, if valve regurgitation has not developed in intermittent cases, follow-up is recommended without the use of antiarrhythmic therapy ${ }^{16,17}$. Fetuses at the highest risk of developing heart failure are those with more persistent SVT, earlier onset of SVT ( $<32$ weeks), and those with structural heart disease, which accounts for $10 \%$ of supraventricular tachyarrhythmias ${ }^{18}$. In our study, all of the fetuses with SVT attacks during the fetal period were at $\geq 37$ weeks of gestation and all of them developed 
intermittent SVT. Only one newborn infant developed heart failure. None of our patients with fetal SVT died. We think that this may be due to the absence of CHD other than ASD and the absence of hydrops in these patients. Although the mortality in SVT is $27 \%$ in fetuses with hydrops, this rate is $<5 \%$ in non-hydropic fetuses ${ }^{19,20}$.

Clinicians should be highly suspicious of SVT because of the potentially terrible problems of untreated SVT ${ }^{1}$. The prognosis of arrhythmias in the neonatal period largely depends on accurate diagnosis and prompt treatment ${ }^{21}$. Synchronized cardioversion is required when circulatory collapse accompanies SVT. If the patient is not critical, it is rational to try vagal maneuver and adenosine first. At an initial dose of $50-100 \mu \mathrm{g} / \mathrm{kg}$, adenosine can be rapidly given intravenously into a large vein. In general, the prognosis of a single SVT treatment is excellent. Usually, drug therapy is recommended to prevent recurrence of SVT in the first year of life ${ }^{8}$. In our patients, 50-100 $\mu \mathrm{g} / \mathrm{kg}$ adenosine was administered in the SVT attack. Since SVT attack was not observed as a clinical finding in 4 of our patients, propranolol was given for maintenance treatment without adenosine administration. All our other patients were given adenosine therapy for SVT attack. Antiarrhythmic drug therapy is somewhat empirical in this population-based on personal experience and observational studies. Recently, there has been a difference in antiarrhythmic prescription models among cardiologists due to additional electrophysiology training ${ }^{6,22}$. In our study, although propranolol treatment was applied very frequently, treatment options such as ivabradine were also given to our patients recently. Side effects related to antiarrhythmic drugs were seen only in one of our patients. While the blood glucose levels were regulated in our patient, whom we admitted to our unit due to hypoglycemia due to hyperinsulinism, hypoglycemia attacks due to propranolol started and we had to terminate the propranolol treatment.

\section{CONCLUSİON}

SVT is one of the most common cardiac emergencies in newborn infants. Early diagnosis and treatment of SVT is very important in terms of reducing morbidity and mortality. Therefore, we think that increasing SVT awareness of clinicians who monitor newborn infants will benable newborns with SVT to receive early diagnosis and treatment.

Ethics Committee Approval: Ethics committee approval was obtained from the ethics committee of Dr. Sami Ulus Maternity and Children Research and Training Hospital, University of Health Sciences of Turkey (Ethics committee number: E-20/12-36).

Conflict of Interest: No conflict of interest was declared by the authors.

Financial Disclosure: No financial disclosure was declared by the authors.

\section{REFERENCES}

1. Spearman AD, Williams P. Supraventricular tachycardia in infancy and childhood. Pediatric annals. 2014; 43: 456-60.

2. O'Connor BK, Dick M, 2nd. What every pediatrician should know about supraventricular tachycardia. Pediatric annals. 1991; 20: 368,71-6.

3. Gilljam T, Jaeggi E, Gow RM. Neonatal supraventricular tachycardia: outcomes over a 27year period at a single institution. Acta paediatrica. 2008; 97: 1035-39.

4. Srinivasan C, Balaji S. Neonatal supraventricular tachycardia. Indian Pacing Electrophysiol J. 2019; 19: 222-31.

5. Bilici M, Demir F. Pediatrik disritmiler. Dicle Tıp Dergisi. 2015; 42: 128-35.

6. Guerrier K, Shamszad P, Czosek RJ, et al. Variation in Antiarrhythmic Management of 
Infants Hospitalized with Supraventricular Tachycardia: A Multi-Institutional Analysis. Pediatr Cardiol. 2016; 37: 946-52.

7. Ban JE. Neonatal arrhythmias: diagnosis, treatment, and clinical outcome. Korean J Pediatr. 2017; 60: 344-52.

8. Malekian A, Khalilian MR, Dehdashtian M, Aramesh MR, Heydaripoor K. Evaluation and Management of Neonatal Supraventricular Tachycardia. J. Compr. Pediatr. 2016; 7: 3.

9. Stambach D, Bermet V, Bauersfeld U. Clinical recognition and treatment of atrial ectopic tachycardia in newborns. Swiss Mes Wkly. 2007; 137: 402-6.

10. Wu MH, Chen HC, Kao FY, Huang SK. Postnatal cumulative incidence of supraventricular tachycardia in a general pediatric population: A national birth cohort database study. Heart rhythm. 2016; 13: 2070-75.

11. Bjeloševič $M$, Illíková $V$, Tomko J, et al. Supraventricular tachyarrhythmias during the intrauterine, neonatal, and infant period: A 10-year population-based study. Pacing Clin Electrophysiol. 2020; 43: 680-86.

12. Jr GA, A L. Supraventricular tachycardia. The Science and Practice of Pediatric Cardiology. 1990; 3: 1809-48.

13. Etheridge SP, Judd VE. Supraventricular tachycardia in infancy: evaluation, management, and follow-up. Archives of pediatrics \& adolescent medicine. 1999; 153: 267-71.

14. Hrtankova M, Biringer K, Siváková J, et al. Fetal magnetocardiography: a promising way to diagnose fetal arrhytmia and to study fetal heart rate variability?. Ceska Gynekol. 2015; 80: 58-63.

15. Kothari D, Skinner J. Neonatal tachycardias: an update. Archives of disease in childhood Fetal and neonatal edition. 2006; 91: F136.

16. Oudijk MA, Visser GH, Meijboom EJ. Fetal tachyarrhythmia-Part I: diagnosis. Indian Pacing Electrophysiol. 2004; 4: 104.

17. Cuneo BF, Strasburger JF. Management strategy for fetal tachycardia. Obstetrics \& Gynecology. 2000; 96: 575-81.

18. Naheed ZJ, Strasburger JF, Deal BJ, Woodrow Benson D, Gidding SS. Fetal tachycardia: mechanisms and predictors of hydrops fetalis. J Am Coll Cardiol. 1996; 27: 1736-40.

19. Jaeggi ET, Carvalho JS, De Groot E, et al. Comparison of transplacental treatment of fetal supraventricular tachyarrhythmias with digoxin, flecainide, and sotalol: results of a nonrandomized multicenter study. Circulation. 2011; 124: 1747-54.

20. Simpson J, Sharland G. Fetal tachycardias: management and outcome of 127 consecutive cases. Heart. 1998; 79: 576-81.

21. Kundak AA, Dilli D, Karagöl B, et al. Non benign neonatal arrhythmias observed in a tertiary neonatal intensive care unit. Indian J Pediatr. 2013; 80: 555-59.

22. Wong KK, Potts JE, Etheridge SP, Sanatani S. Medications used to manage supraventricular tachycardia in the infant a North American survey. Pediatr Cardiol. 2006; 27: 199-203. 